\title{
Association study with two markers of a human homeogene in infantile autism
} Elisabeth Petit, Josiane Hérault, Joëlle Martineau, Anne Perrot, Catherine Barthélémy,
Laurence Hameury, Dominique Sauvage, Gilbert Lelord, Jean Pierre Müh connections within and between brain regions. $^{12-14}$ More recently, a cerebellar hypothesis has been proposed: the cerebellum controls motility ${ }^{15}$ and regulation of perception. ${ }^{16}$ In 1988 Courchesne $e t a l^{8}$ reported hypoplasia of lobules VI and VII of the cerebellar vermis in 14 autistic subjects. Histological studies of the cerebellum have also shown abnormalities, the characteristics of which suggest that they are the consequence of a curtailment of the development of portions of the limbic system and cerebellar circuits. ${ }^{17-19}$ These results indicate the possibility of mutations of genes involved in the development of these structures.

Results of epidemiological and family studies in autism have shown that there is a genetic susceptibility factor in this syndrome and a significant sex difference was observed with a pooled male-female ratio of approximately $3: 1{ }^{20}$ Moreover, the prevalence of autism was greater in sibs when one child was already affected. ${ }^{21}$ Finally, twin studies showed that concordance rates for monozygotic twins were greater than for dizygotic twins. ${ }^{22-24}$ Association and linkage studies in autism with several markers did not give convincing results. However, the possible association of two markers of the c-Harvey-ras oncogene with autism has been identified. ${ }^{25} 26$

These various data encourage consideration of developmental genes of the CNS, and the genes with homeobox look particularly interesting. ${ }^{27}$ These genes encode for a basic homeoprotein which has the property of binding DNA. Therefore the products of homeogenes may have a role in the regulation of the expression of other genes. More precisely, the homeobox peptides might regulate important events in the morphological differentiation of the postmitotic neurone. ${ }^{28}$ The "engrailed" and "invected" homeogenes are segmentation genes in Drosophila and have homologous genes in the mouse, $E n-1$ and $E n-2$. These two genes are expressed in the cerebellum of fetal and adult mice. ${ }^{29}{ }^{30}$ Moreover, abnormal foliation was observed in the adult cerebellum of a mouse in which the $E n-2$ gene had been partly deleted. ${ }^{31}$ Human homologous EN-1 and EN-2 genes are located on chromosome 7 (q36-qter) and on chromosome 2 (q13-q21) respectively. ${ }^{3233}$ In this association study with 100 autistic and 100 control children, two probes of the EN-2 gene were used. The first probe, MP4, is located within the $5^{\prime}$ region of the EN-2 gene. ${ }^{34}$ The second probe, MP5, is located within the homeobox and ex-
Received 6 September 1994 Revised version accepted for publication 28 November publicati volvement of the cortical association area, including the frontal lobes, and neural 
tends to the end of the $3^{\prime}$ region..$^{35}$ The precise location of these two RFLPs is still unknown.

\section{Methods}

SUBJECTS

The children in the control and patient groups were white and of western or central French descent.

Forty-five of the 100 autistic children were day patients from the Child Psychiatry Day Care Unit of the Centre Hospitalier Regional Universitaire (CHRU) of Tours (France). The others came from several other care units and had two days of intensive examination in order to confirm their diagnosis of autism and to undergo further examinations. All selected children showed marked autistic behaviour including lack of responsiveness to other people, poor social interaction, language impairment, bizarre responses to the environment, and stereotyped sensorimotor activity. Children under 3 years ignored people, had no social smile, and no appropriate expressive gestures and postures. They were either too calm or overexcited and began to have stereotyped behaviour. The children were all unrelated (34 girls and 66 boys) with a mean age of 7 years 4 months (range 2-16 years) at the time of sampling. Informed parental consent was obtained for all children.

The control group (46 girls and 54 boys; mean age 8 years 2 months) comprised 100 unrelated children with no known neurological dysfunction or treatment. These children were chosen from normal local school populations and matched the subjects with autism for chronological age. They remained anonymous. All the children had normal educational achievement for age.

The protocol of blood sampling and DNA study was approved by a local ethics committee.

\section{CLINICAL ASSESSMENTS}

Each autistic child received an extensive evaluation, including a detailed developmental history using questionnaires, a videotaped psychiatric assessment, psychological and linguistic testing, paediatric and neurological examination, and audiological assessment. Examinations were carried out by a professional team of child psychiatrists and a child psychologist, language pathologist, neurologist, and paediatrician, all expert in dealing with autistic children. A diagnosis of infantile autism was reached only if all, or all but one of the six members of the team, agreed that the child's condition met all the criteria of early infantile autism listed in the DSM III-R. ${ }^{3}$ These criteria included qualitative impairment in reciprocal and social interaction, qualitative impairment in communication and imaginative activity, and a markedly restricted repertoire of activities and interests. They were evaluated after semistructured interview of their parents and after all examinations had been performed.

Autistic behaviour, ${ }^{36}$ cognitive disorders, ${ }^{37}$ neurological syndromes, ${ }^{38}$ and language disorders ${ }^{39}$ were studied. The signs of autism were evaluated on the basis of a thorough clinical examination and on a synthesis largely based on the terminology of the DSM III-R classification. The cognitive disorders were evaluated with a complete psychological examination, using the Brunet-Lezine ${ }^{40}$ psychomotor development test (French adaptation of Gesell and Amatrudas Scale ${ }^{41}$ ). The degree of retardation was scored using the DSM III-R criteria. $(\mathrm{DQ}>70=$ very mild or no retardation, $69>\mathrm{DQ}>50=$ mild retardation, $49>\mathrm{DQ}>35=$ moderate retardation, $34>\mathrm{DQ}>20=$ severe retardation, $20>\mathrm{DQ}=$ profound retardation). The neurological syndromes were evaluated with a complete neurological examination, EEG, brain mapping, scanning, and brain imaging methods. Scores, using a grid, included the intensity of neurological syndromes and any associated epileptic disorders. ${ }^{42}$ Language disorders were evaluated with a complete speech test examination and an evaluation scale of verbal and pre-verbal communication. ${ }^{43}$ Each of these four evaluations were rated from none (1) to profound (5) for the 100 autistic children.

Clinical evaluation was completed by using a behaviour rating scale (Behavior Summarized Evaluation: BSE scale ${ }^{445}$ ) which supplies information on the current behaviour of the child. It consists of 29 items rated on a five point scale ranging from never (1) to always (5). Day patients from the Child Psychiatry Day Care Unit of the CHRU of Tours were rated once a week by two independent observers who conferred on the weekly ratings to produce the final score. These two observers were nurses who had known the children for several months and who had daily contact with them. The other children were rated during two days by two independent observers, expert in evaluating autistic children. For the children under 3 years old, a scale very similar to the BSE scale, the Infant Behaviour Summarized Evaluation Scale (I-BSE), was used. $^{46}$ Sauvage, ${ }^{47}$ Gillberg, ${ }^{48}$ and Dahlgren and Gillberg ${ }^{49}$ showed that infants were already impaired in several areas such as social relations, communication, and perception. All these children were followed in our Department. Today, they are over 3 years and the diagnosis of autism was confirmed in each case.

Genetic factors were evaluated on the basis of a double evaluation ${ }^{50}$ : evaluation of family history and genetic somatic signs through a thorough clinical examination. Family history was rated from (1) to (5); an autistic child with score 1 has no family history and a child with score 5 has at least two relatives with mental retardation or psychiatric disorders or both. Evaluation of genetic somatic signs was rated from none (1) to confirmation of genetic disease (5). Detailed descriptions are given in table 1.

For each autistic child, fragile $\mathrm{X}$ syndrome was sought by Southern blotting using probe StB12.3.

\section{DNA STUDIES}

Genomic DNA was extracted from EDTA anticoagulated blood. The polymorphism for 
Table 1 Genetic evaluation performed on the rating of family history and clinical examination used for the 100 autistic children

\begin{tabular}{lcccc}
\hline Family history & Yes & Probable & No & $\begin{array}{c}\text { Types of } \\
\text { relationship }\end{array}$ \\
\hline
\end{tabular}

Spontaneous abortion/stillborn

Mental retardation

Psychiatric disorders

Specific developmental disorders

Others (neuro, genet, other diseases)

Clinical examination

Genetic factors are

\begin{tabular}{lll}
\hline 1 Absent & Clinical examination is negative \\
2 Arguable & Isolated peculiarity (morphology ...) \\
3 Possible & Dysmorphology/malformations \\
4 Probable & A genetic disease is evoked \\
5 Sure & Confirmation of a genetic disease \\
\hline
\end{tabular}

the MP4 and MP5 probes ${ }^{3435}$ was analysed by Southern blotting. ${ }^{25}$ With the MP4 probe, PruII identifies one invariant band at $1.4 \mathrm{~kb}$ and a simple two allele polymorphism with a band at either $1.2 \mathrm{~kb}$ (allele 1 ) or $1.0 \mathrm{~kb}$ (allele 2). With the MP5 probe, SstI identifies a simple two allele polymorphism with a band at $11 \mathrm{~kb}$ (allele 1) and $6.8 \mathrm{~kb}$ (allele 2). These DNA probes were provided by A Joyner.

\section{STATISTICAL METHODS}

The allele frequency was calculated by counting the number of alleles of each type and expressing each allele frequency as a proportion of the total number of alleles typed. The $\chi^{2}$ test was used in statistical analyses. Because two $\chi^{2}$ tests were carried out (MP4 and MP5 probes), we applied Bonferroni's multiple comparison procedure. A significance level of 0.025 was used (that is, $0.05 / 2$ ).

A discriminant analysis was performed using a stepwise variable selection procedure. Intragroup comparisons using Kruskal-Wallis

Table 2 Clinical profile performed with the Behaviour Summarised Evaluation (BSE) scale for the autistic group

\begin{tabular}{|c|c|c|c|}
\hline Iten & & Mean & $S E M$ \\
\hline 1 & Aloneness & 2.96 & $0 \cdot 12$ \\
\hline & Ignores people & 2.90 & 0.13 \\
\hline & Poor social interaction & 3.63 & $0 \cdot 11$ \\
\hline & Abnormal eye contact & $2 \cdot 65$ & $0 \cdot 12$ \\
\hline & Does not make an effort to & & \\
\hline & $\begin{array}{l}\text { communicate using voice/words } \\
\text { Lack of appropriate facial expressions }\end{array}$ & $3 \cdot 76$ & $0 \cdot 13$ \\
\hline & and gestures & $3 \cdot 28$ & $0 \cdot 13$ \\
\hline & $\begin{array}{l}\text { Stereotyped vocal or verbal } \\
\text { utterances, echolalia }\end{array}$ & $2 \cdot 33$ & 0.14 \\
\hline \multirow[b]{2}{*}{9} & Lack of initiative, poor activity & 3.68 & 0.12 \\
\hline & $\begin{array}{l}\text { Inappropriate relating to inanimate } \\
\text { obects or to doll }\end{array}$ & 3.33 & 0.14 \\
\hline 10 & Irresistible/ritual use of objects & $\begin{array}{l}3.33 \\
2 \cdot 89\end{array}$ & $\begin{array}{l}0.14 \\
0.16\end{array}$ \\
\hline 11 & Intolerance of change and frustration & $2 \cdot 76$ & $0 \cdot 13$ \\
\hline 12 & Stereotyped sensorimotor activity & 3.02 & 0.14 \\
\hline 13 & Agitation, restlessness & $2 \cdot 44$ & 0.14 \\
\hline 14 & Bizarre posture and gait & 3.41 & $0 \cdot 13$ \\
\hline 15 & Autoaggressiveness & 1.72 & $0 \cdot 10$ \\
\hline 16 & Heteroaggressiveness & 1.89 & $0 \cdot 11$ \\
\hline 17 & Mild anxiety signs & $2 \cdot 86$ & $0 \cdot 10$ \\
\hline 18 & Mood difficulties & $2 \cdot 18$ & $0 \cdot 13$ \\
\hline \multirow[b]{2}{*}{20} & Disturbances of feeding behaviour & $2 \cdot 68$ & 0.13 \\
\hline & Does not try to be clean (stools or & & \\
\hline & $\begin{array}{l}\text { urine), plays with stools } \\
\text { Individual bodily activities }\end{array}$ & $\begin{array}{l}2 \cdot 45 \\
1 \cdot 81\end{array}$ & $\begin{array}{l}0 \cdot 16 \\
0 \cdot 12\end{array}$ \\
\hline 22 & Sleep problems & 1.63 & $0 \cdot 10$ \\
\hline & Unstable attention, easily distracted & 3.57 & $0 \cdot 11$ \\
\hline 24 & Bizarre responses to auditory stimuli & $2 \cdot 38$ & 0.13 \\
\hline \multirow{6}{*}{$\begin{array}{l}26 \\
27 \\
28 \\
29\end{array}$} & Variability & $2 \cdot 09$ & $0 \cdot 12$ \\
\hline & Does not imitate the gestures or & & \\
\hline & $\begin{array}{l}\text { voices of others } \\
\text { Child too floppy, lifeless }\end{array}$ & $\begin{array}{r}3.29 \\
2.02\end{array}$ & $\begin{array}{l}0.14 \\
0.12\end{array}$ \\
\hline & Does not share emotion & $3 \cdot 36$ & $0 \cdot 12$ \\
\hline & Paradoxical sensitivity to touching & & \\
\hline & and contact & $2 \cdot 38$ & $0 \cdot 13$ \\
\hline
\end{tabular}

one way analysis of variance (ANOVA) was performed. SPSS subprograms were used.

\section{Results}

CLINICAL RESULTS

The distribution of scores for autistic behaviour, cognitive disorders, neurological syndromes, and language disorders in the population of 100 autistic children were as follows: 76 children had high scores (3, 4, or 5) for autistic behaviour, 75 for cognitive disorders, and 90 for language disorders. Seventy-four children scored 1 or 2 for neurological disorders.

The mean and the standard errors of the mean of ratings with the BSE scale for the autistic group are given in table 2. Higher scores were found for items related to autistic symptoms, for example, item 3 (3.63), item 5 $(3 \cdot 76)$, item $6(3 \cdot 28)$, item $8(3.68)$, item 9 (3.33), item $12(3.02)$, item $14(3.41)$, item $23(3 \cdot 57)$, item $26(3 \cdot 29)$, and item $28(3 \cdot 36)$.

Evaluation of family history showed 42 children with no known family history (score 1) and 47 children with mild disorders in distant relatives (scores 2 and 3 ). Nine children had a family history of mental retardation or psychiatric disorders or both among parents or close relatives (score 4 ). Two children had a score of 5 because there was mental retardation in parents and close relatives. The clinical examination for genetic signs showed 49 children with completely negative results (score 1 ) and 38 children with isolated peculiarity, dysmorphology, or malformations (scores 2 and 3). Seven children probably had genetic disease (score 4): signs of Cohen syndrome, FG syndrome, Marfan syndrome, Rett syndrome, arginosuccinic acid synthetase deficiency, congenital agenesis of the corpus callosum, and familial encephalopathy of unknown aetiology. Six children had proven genetic disease (score 5). One child was XYY male and the other five children had Angelman syndrome, FG syndrome, Waardenburg syndrome, fra $(\mathrm{X})$ syndrome, and San Filippo syndrome (mucopolysaccharidosis III) respectively. Only one child belonged to the two groups with score 5 for family history and for genetic somatic signs.

\section{GENETIC RESULTS}

Allele frequencies, $\chi^{2}$ values, and genotype counts in the patients and the controls for the two markers are shown in table 3 . Significant differences in the allele distributions between the two populations were shown by $\chi^{2}$ analysis using the MP4 probe $\left(\chi^{2}=7 \cdot 99, \mathrm{df}=1, \mathrm{p}<0.01\right)$ whereas no difference was shown with the MP5 probe $\left(\chi^{2}=1 \cdot 17, \mathrm{df}=1\right.$, not significant $)$. After the Bonferroni correction was applied, the allele distributions for the MP4 probe in the autistic children were still statistically different from those in the control group $(p<0.025)$. The number of each genotype observed in the control group did not differ significantly from the values expected according to Hardy-Weinberg equilibrium (MP4 probe: $\chi^{2}=2 \cdot 56, \mathrm{df}=2$, p $>0.05$; MP5 probe: $\left.\chi^{2}=3.31, \mathrm{df}=2, \mathrm{p} \cdot 0.05\right)$. 
Table 3 Allele frequencies, $\chi^{2}$ values, and genotype counts in the patients and the controls for the two probes of the EN-2 gene

\begin{tabular}{|c|c|c|c|c|c|c|c|c|}
\hline & & \multirow[t]{2}{*}{ No } & \multicolumn{2}{|c|}{ Allele frequencies } & \multirow[t]{2}{*}{$x^{2}$} & \multicolumn{3}{|c|}{ Genotypes } \\
\hline & & & 1 & 2 & & $1-1$ & $1-2$ & $2-2$ \\
\hline \multirow[t]{2}{*}{ MP4 probe } & Controls & 100 & 0.5 & 0.5 & \multirow{2}{*}{$\begin{array}{l}7.99 \\
p<0.01\end{array}$} & 29 & 42 & 29 \\
\hline & Patients & 100 & 0.36 & $0 \cdot 64$ & & 14 & 44 & 42 \\
\hline \multirow[t]{2}{*}{ MP5 probe } & Controls & 100 & 0.86 & $0 \cdot 14$ & \multirow{2}{*}{$\begin{array}{l}1.17 \\
p>0.05\end{array}$} & 77 & 19 & 4 \\
\hline & Patients & 100 & 0.83 & $0 \cdot 17$ & & 71 & 25 & 4 \\
\hline
\end{tabular}

The same result was observed for the autistic group (MP4 probe: $\chi^{2}=0 \cdot 20, \mathrm{df}=2, \mathrm{p}>0 \cdot 05$; MP5 probe: $\left.\chi^{2}=0.85, \mathrm{df}=2, \mathrm{p}>0.05\right)$.

No significant difference in genotype counts was observed between heterozygote and homozygote in each population for the two probes (MP4 probe: $\chi^{2}=0.08, \mathrm{df}=1, \mathrm{NS}$; MP5 probe: $\left.\chi^{2}=1 \cdot 04, \mathrm{df}=1, \mathrm{NS}\right)$. There was a tendency for the 2-2 genotype to be more common in the patients than controls for the MP4 probe $\left(\chi^{2}=7 \cdot 57, \mathrm{df}=1, \mathrm{p}<0 \cdot 01\right)$ but not for probe MP5 $\left(\chi^{2}=0 \cdot 51, \mathrm{df}=1, \mathrm{NS}\right)$.

\section{RELATIONSHIP BETWEEN CLINICAL AND GENETIC} RESULTS

The distribution of the MP4 probe was analysed according to family history, genetic somatic signs, results of clinical examinations, and the intensity of scores in each of these categories. The same difference in allele distribution was always observed between the normal and the autistic population whatever the scores in family history: if children with score 5 were excluded from the comparison, the difference remained $\left(\chi^{2}=6 \cdot 07, \mathrm{df}=1, \mathrm{p}<0.02\right)$. When the children with score 5 for somatic genetic signs were excluded, the $\chi^{2}$ value was less significant $\left(\chi^{2}=4 \cdot 87, \mathrm{df}=1, \mathrm{p}<0 \cdot 05\right)$.

As most of the children had high scores in autistic behaviour and low scores in neurological disorders, our sample could be divided into three groups according to their cognitive functioning: group I ( 25 children) with mild impairment (score 1 and 2), group II ( 31 children) with moderate impairment (score 3 ), and group III ( 44 children) with severe impairment (scores 4 and 5). There was no significant difference between clinical groups I, II, and III for allele distribution. If we considered the three groups of patients (table 3 ) determined by their genotype for the MP4 probe (homozygous 1-1: 14 children, homozygous 2-2: 42 children, and heterozygous 1-2: 44 children), no more significant difference appeared between these three groups for clinical data. The three "genotypical" groups did not correspond to the three "clinical" groups.

Moreover, discriminant analysis was performed between the three "genotypical" groups and the scores for autistic behaviour, cognitive syndrome, neurological syndromes, and language disorders. None of the scores for each of four evaluations allowed discrimination of the three genotypes. We also compared the allele distribution for each evaluation between children with scores 1,2 , and 3 and those with scores 4 and 5 . The results were not significant (autistic behaviour: $\chi^{2}=0.55$, NS; cognitive disorders: $\chi^{2}=1 \cdot 9$, NS; neurological syndromes: $\chi^{2}=1 \cdot 17$, NS; language disorders: $\chi^{2}=$ $0 \cdot 15$, NS).

Discriminant analysis between the three genotypes was also performed on the items of the BSE scale. Item 19 (disturbance of feeding behaviour) allowed discrimination between the three genotypes. This result was confirmed by the Kruskal-Wallis non-parametric test $\left(\chi^{2}=\right.$ 13.25, $\mathrm{p}=0 \cdot 013$ ).

\section{Discussion}

The clinical data obtained with the BSE scale and the evaluation of autistic behaviour, cognitive disorders, neurological syndromes, and language disorders confirmed the diagnosis of autism in the patient population according to DSM III-R. Relevant somatic genetic signs scored 4 and 5 were present in 13 of these 100 children. Gillberg and Wahlstrom ${ }^{52}$ found three cases of XYY males among 55 autistic children. San Filippo syndrome has been associated with mental retardation in a case report. ${ }^{53} \mathrm{We}$ could not find any association of Cohen syndrome, Waardenburg syndrome, Marfan syndrome, Angelman syndrome, or FG syndrome (which is an $\mathrm{X}$ linked syndrome) with autism in published reports, nor association between autism and arginosuccinic acid synthetase deficiency.

Among the 100 autistic children in our study, only one child had fra $(\mathrm{X})$ syndrome detected by molecular biological methods. The percentage of fra(X) subjects identified among autistic populations varies considerably according to different studies. ${ }^{54}$ Finally, one autistic girl in our population had suspected Rett syndrome. The principal common feature between Rett and autistic syndromes is the existence of stereotypic behaviours. ${ }^{55}$ However, these two syndromes have a distinct evolution in time and the results of studies by Ollson and $\operatorname{Rett}^{56}$ show important differences between them.

Eleven percent of families of autistic children in our study have mental retardation or psychiatric disorders or both in parents or close relatives. Aggregation of cognitive disorders and severe social deficits in the families and relatives of autistic probands has been described. ${ }^{57}$ Several studies have reported the presence of particular psychiatric disorders in the families of autistic subjects. Recurrent major affective disorder is also more common in the parents of autistic probands, although the difference compared with control subjects does not reach statistical significance.

In this association study we show that allele 2 of the MP4 probe is significantly associated with the autistic population. Homogeneity of the two populations was confirmed by the fact that the observed genotype distribution was close to the values expected on the basis of Hardy-Weinberg equilibrium. For the validation of these preliminary results, such a study must be repeated on control and autistic populations from other homogeneous ethnic 
groups. The preponderance of allele 2 for the MP4 probe in the autistic population, if it is checked, could show that the RFLP of the EN2 gene is related to or is in linkage disequilibrium with a genetic factor that has an effect on the pathophysiology of autism. This gene is closely related to the Drosophila segmentation gene "engrailed" and to the corresponding mouse gene required for the development of parts of the CNS shown by gene expression studies during mouse embryogenesis. This gene is therefore a good candidate in the genetic study of this syndrome considered to involve brain developmental aspects. It is necessary to know its precise expression in the human cerebellum and its function in the foliation of this structure. Finally, absence of linkage disequilibrium between markers MP4 and MP5 could direct the research of the definite location of the locus involved to the EN-2 gene.

Dividing the overall group of 100 autistic children into subgroups according to clinical data did not give more definite information. The preponderance of allele 2 in the autistic population is not as significant when the patients with high somatic genetic scores are removed. However, the several genetic syndromes present in this subgroup have no known relationship with the EN-2 gene. Discriminant analysis of the items of the BSE scale between the three genotypes given by the MP4 probe sets item 19 apart. This item (Disturbance of feeding behaviour) is scored in many autistic children. Finally, the comparison between clinical and genetic results shows no obvious relationship between particular genotype and clinical profile.

From now on, cerebral imaging data look promising for defining other subgroups. Reversed cerebral asymmetry ${ }^{58}$ and enlargement of the lateral and third ventricles ${ }^{5960}$ have been shown in autistic subjects by CT scanning. In vivo approaches to brain function by positron emission tomography (PET) and single photon emission computed tomography (SPECT) are now available. ${ }^{6162}$ In vivo studies of the cerebellum with anatomical and functional imaging methods such as magnetic resonance imaging, PET, or SPECT scans should specify the potential abnormalities in this structure. Exchanges between neuroanatomical and molecular biological research could provide further information on the choice of candidate genes for genetic studies in autism.

This study was supported by INSERM U316, INSERM Network 493001, CNRS UPR 23, Grants CRE INSERM 911008 (Dr L Hameury), Conseil Régional de la Région Centre, INSERM-France Telecom convention 1993, Fondation Langlois. We thank Ms C Cherpi for her technical assistance and Dr Raynaud (Department of Genetics, Pr Moraine) for her participation in diagnosis of fragile $\mathrm{X}$ syndrome in the autistic population.

1 Kanner L. Autistic disturbances of affective contact. Nerv Child 1943;2:217-50.

2 Lelord G, Sauvage D. L'autisme de l'enfant. Paris: Mason, 1991.

3 American Psychiatric Association. Diagnostic and statistical manual of mental retardation. 3rd ed, revised. Washington, DC: American Psychiatric Press, 1987

4 Garreau B, Zilbovicius M, Bruneau N, et al. Etude de débit sanguin et du métabolisme cérébral dans l'autisme infantile. Neuropsy Enf Adolesc 1992;7:89-104.

5 Ornitz EM, Ritvo ER. Neurophysiologic mechanisms underlying perceptual inconstancy in autistic and schizophrenic children. Arch Gen Psychiatry 1968;19:22-7.

6 Ornitz EM. Neurophysiology of infantile autism. $7 \mathrm{Am} \mathrm{Acad}$ Child Psychiatry 1985;24:251-62.

7 Tanguay PE, Edwards RM, Buchwald J, Schwafel J, Allen V. Auditory brainstem evoked responses in autistic children. Arch Gen Psychiatry 1982;39:174-80.

8 Courchesne E, Yeung-Courchesne R, Press GA, Hesselink JR, Jernigan TL. Hypoplasia of cerebellar vermal lobules VI and VII in autism. N Engl f Med 1988;318:1349-54

9 Delong GR, Bean SC, Brown FR. Acquired reversible autistic syndrome in acute encephalopathic illness in children. Arch Neurol 1981;28:191-4.

10 Bauman ML, Kemper TL. Histoanatomic observations of the brain in early infantile autism. Neurology 1985;35: $866-74$.

11 Bachevalier J. Memory loss and socio-emotional disturbances following neonatal damage of the limbic system in monkeys. In: Advances in psychiatry. Volume 1. Schizophrenia. New York: Raven Press, 1990.

12 Courchesne E, Lincoln AJ, Yeung-Courchesne R, Elmasian $\mathrm{R}$, Grillon C. Pathophysiology findings in non-retarded autism and receptive developmental language disorders. f Autism Dev Disord 1989;19:1-17.

13 Rumsey JM, Hamburger SD. Neuropsychological findings in high-functioning men with infantile autism, residual state. $\mathcal{F}$ Clin Exp Neuropsychol 1988;10:201-21.

14 Minshew NJ, Goldstein G. Autism: a distributed neural network deficit? f Clin Exp Neuropsychol 1992;15:56.

15 Ito N. The cerebellum and neural control. New York: Raven Press, 1984.

16 Leaton RN, Supple WF. Cerebellar vermis: essential for longterm habituation of the acoustic startle response. Science 1986;235:513-15.

17 Bauman ML, Kemper TL. Histoanatomic observations of the brain in early infantile autism. Neurology $1985 ; 35$. 866-74.

18 Ritvo ER, Freeman BJ, Scheibel AB, et al. Lower Purkinje cell counts in the cerebella of four autistic subjects: initial findings of the UCLA-NSAC autopsy research report. $A m$ f Psychiatry 1986;143:862-6.

19 Bauman ML. Microscopic neuroanatomic abnormalities in autism. Pediatrics 1991;87:791-6.

20 Ritvo ER, Jorde LB, Mason-Brothers A. The UCLA University of Utah epidemiologic survey of autism: recurrence risk estimates and genetic counseling. Am $\mathcal{f}$ Psychiatry 1989;146:1032-6.

21 August GJ, Stewart MA, Tsai L. The incidence of cognitive disabilities in the siblings of autistic children. $B r f P$ Psychiatry 1981;138:416-22.

22 Folstein S, Rutter M. Infantile autism: a genetic study of 21 twin pairs. F Child Psychol Psychiatry 1977;18:297-321.

23 Ritvo ER, Freeman BJ, Mason-Brothers A, Mo A, Ritvo AM. Concordance for the syndrome of autism in 40 pairs
AM. AM. Concordance for the syndrome of autism in 40
of afflicted twins. Am $\mathcal{F}$ Psychiatry 1985;142:74-7.

24 Steffenburg S, Gillberg C, Hellgren L, et al. A twin study of autism in Denmark, Finland, Ireland, Norway and Sweden. F Child Psychol Psychiatry 1989;3:405-16.

25 Hérault J, Perrot A, Barthélémy C, et al. Possible association of c-Harvey-ras-1 (HRAS 1) marker with autism. Psychiatr Res 1993;46:261-7.

26 Hérault J, Petit E, Martineau J, et al. Autism and genetics: clinical approach and association study with two markers of HRAS gene. Am f Med Genet (in press).

27 Sims KB, Caviness VS. Molecular genetics and mental retardation. In: Brosius J, Fremeau RT, eds. Molecular genetic approaches to neuropsychiatric diseases. San Diego: Academic Press, 1991

28 LeRoux I, Joliot AH, Bloch-Gallego E, Prochiantz A, Volovitch $M$. Neurotrophic activity of the Antennapedia homeodomain depends on its specific DNA-binding prophomeodomain depends on its specific DNA-bind

29 Davis CA, Joyner AL. Expression patterns of the homeoboxcontaining genes $E n-1$ and $E n-2$ and the proto-oncogene int-1 diverge during mouse development. Genes Dev 1988; int-1 diverge

30 Davis GA, Noble-Topham SE, Rossant J, Joyner A. Expression of the homeobox-containing gene En-2 delineates a specific region of the developing mouse brain. Genes Dev 1988;2:361-71.

31 Joyner AL, Herrup BA, Auerbach A, Davis CA, Rossant J. Subtle cerebellar phenotype in mice homozygous for a targeted deletion of the En-2 homeobox. Science 1991; 251:1239-43.

32 Poole JJ, Law ML, Kao FT, Lau YF. Isolation and chromosomal localization of the human En-2 gene. Genomics $1988 ; 4: 225-31$

33 Köhler A, Logan C, Joyner AL, Muenke M. Regional assignment of human homeobox-containing gene EN-1 to chromosome 2q13-q21. Genomics 1993;15:233-5.

34 Logan C, Joyner AL. An SstI RFLP for the human homeobox-containing gene EN-2. Nucleic Acids Res 1989; 17:2878.

35 Logan C, Joyner AL. PvuII and RsaI RFLPs for the human homeobox-containing gene EN-2. Nucleic Acids Res 1989; 17:2879.

36 Barthélémy C, Lelord G. Les échelles d'évaluation clinique en psychiatrie de l'enfant. Paris: Expansion Scientifique en psychiatrie de

37 Adrien JL. Intérêt des évaluations psychologiques dans les troubles graves du développement. Neuropsychiatr Enfance Adolesc 1986;34:63-91. 
38 Garreau B, Bruneau N, Martineau J. Autisme et psychoses de l'enfant. Signes neurologiques et examens complémentaires. Soins $P$ nych

39 Dansart P, Barthélémy C, Adrien JL, Sauvage D, Lelord G. Troubles de la communication pré-verbale chez l'enfan autistique: mise au point d'une échelle d'évaluation. $A c$ tualités Psychiatriques 1988;4:38-43.

40 Brunet $O$, Lezine I. Echelle de développement psychomoteur de la première enfance. In: Brunet $\mathrm{O}$, Lezine I, eds. Le developpement psychologique de la première enfance. 2nd ed. Paris : PUF, 1976.

41 Gesell A, Amatruda CS. Normal and abnormal child development. Clinical methods and pediatric applications. New York: Haeber, 1944.

42 Garreau B, Barthélémy C, Sauvage D, Leddet I, Lelord G. A comparison of autistic syndromes with and without associated neurological problems. $₹$ Autism Dev Disord 1984;14:105-11.

43 Dansart P, Pallado L, Lenoir P. Evaluation du langage. In Lelord G, Sauvage D, eds. L'autisme de l'enfant. Paris:

44 Lelord G, Müh JP, Barthélémy C, Martineau J, Garreau B Effects of pyroxidine and magnesium on autistic symp toms. Initial observations. $\mathcal{F}$ Autism Dev Disord 1981;11 219-30.

45 Barthélémy C, Adrien JL, Tanguay $\mathrm{P}$, et al. The behaviora summarized evaluation: validity and reliability of a scal for the assessment of autistic behaviors. $\mathcal{f}$ Autism Dev Disord 1990;20:189-203.

46 Adrien JL, Lenoir P, Martineau J, et al. Blind rating of early symptoms of autism based upon family home movies. Am Acad Child Adolesc 1993;32:617-26.

47 Sauvage D. Autisme du nourisson et du jeune enfant. Paris: Masson, 1988.

48 Gillberg C. Early symptoms in autism. In: Gillberg C, ed. Diagnosis and treatment of autism. New York: Plenum Press, 1989.

49 Dahlgren SO, Gillberg C. Symptoms in the first two years of life. A preliminary population study of infantile autism. Eur Arch Psychiatr Neurol Sci 1989;386:1-6.

50 Lenoir P. Antécédents médicaux et familiaux dans les troubles globaux du développement de l'enfant ( 326 cas): étude clinique de la place des facteurs génétiques dans l'autisme. Thèse de Médecine, Faculté de Tours, 1989.

51 Oberlé I, Rousseau F, Hertz D, et al. Instability of a 550base pair DNA segment and abnormal methylation in fragile X syndrome. Science 1991;252:1097-102.

52 Gillberg C, Wahlstrom J. Chromosome abnormalities in infantile autism and other childhood psychoses. A population study of 66 cases. Dev Med Child Neurol 1985;27: 293-304.

53 San Filipo SJ, Podosin R, Langer LO, Good RA. Mental retardation associated with acid mucopolysacchariduria heparin sulfate type. $\mathcal{F}$ Pediatr 1963;63:837-42.

54 Einfeld S, Moloney $\mathrm{H}$, Hall W. Autism is not associated with the fragile X syndrome. Am $\mathcal{F}$ Med Genet 1989;34: 187-93.

55 Hagberg B, Aicardi J, Dias K, Ramos O. A progressive syndrome of autism, dementia, ataxia and loss of pursyndrome of autism, dementia, ataxia and loss of pur-
poseful hand use in girls: Rett syndrome. Ann Neurol 1983; poseful hand

56 Olson B, Rett A. Behaviored observations concerning differential diagnostic between the Rett syndrome and autism. Brain Dev 1985;7:281-9.

57 Folstein SE, Piven J. Etiology of autism: genetic influences. Pediatrics 1991;87:767-73.

58 Hier DB, LeMay M, Rosenberg PB. Autism and unfavorable left-right asymmetries of brain. $\mathcal{f}$ Autism Dev Disord 1979; 9:153-9.

59 Campbell MS, Rosenbloom S, Perry R, et al. Computed axial tomography in young autistic children. $A m \mathcal{F} P s y$ chiatry 1979;9:153-9.

60 Damasio H, Maurer RG, Damasio AR, Chui HC. Computerized tomography scan findings in patients with autistic behavior. Arch Neuml 1980;37:504-10.

61 Rumsey JM, Duara R, Grady C, et al. Brain metabolism in autism. Resting cerebral glucose utilisation rates as measured with positron emission tomography. Arch Gen measured with positron em
Psychiatry 1985;42:448-55.

62 Zilbovicius M, Garreau B, Tzourio N, et al. Regional cerebral blood flow in childhood autism: a SPECT study. Am f Psychiatry 1992;149:924-30. 